\title{
Unilateral interstitial lung disease in a woman aged 35 years
}

\section{Daniel John O'Hare, ${ }^{1}$ Timothy Scanlon, ${ }^{2}$ Cormac Thomas O'Connor, ${ }^{3}$ Aidan O'Brien ${ }^{4}$}

${ }^{1}$ Department of Medicine, University Hospital Limerick, Limerick, Ireland

${ }^{2}$ Department of Radiology, University Hospital Limerick, Limerick, Ireland

${ }^{3}$ Cardiology Department, University Hospital Limerick, Limerick, Ireland

${ }^{4}$ University Hospital Limerick, Limerick, Ireland

\section{Correspondence to}

Dr Daniel John O'Hare, drdanielohare@gmail.com

Accepted 11 January 2017

\section{DESCRIPTION}

A woman aged 35 years presented to the respiratory services with a history of asthma and recurrent lower respiratory tract infections. Chest X-ray (figure 1) showed mediastinal shift, volume reduction and increased interstitial markings throughout the right lung. Pulmonary function testing revealed a mixed obstructive and restrictive pattern.

CT scan demonstrated the absence of the right main pulmonary artery (figure 2). Collateral supply to the right lung was provided from the enlarged right internal mammary and inferior phrenic arteries (figure 3). Fine reticular peripheral interstitial markings, focal areas of ground glass and bronchiolitis were seen in the right lung (figure 4).

Radiographical findings were consistent with a diagnosis of interruption of the right pulmonary artery. This is a rare congenital condition

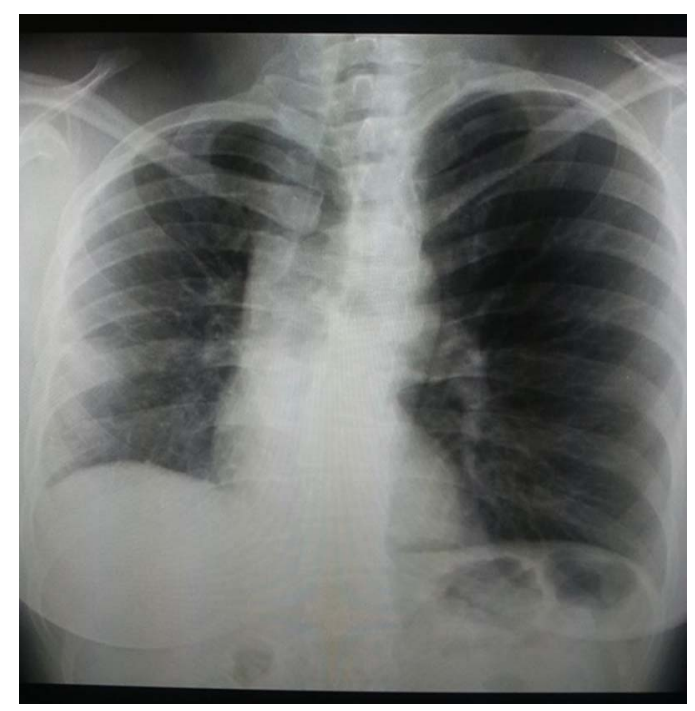

Figure1 Chest X-ray.

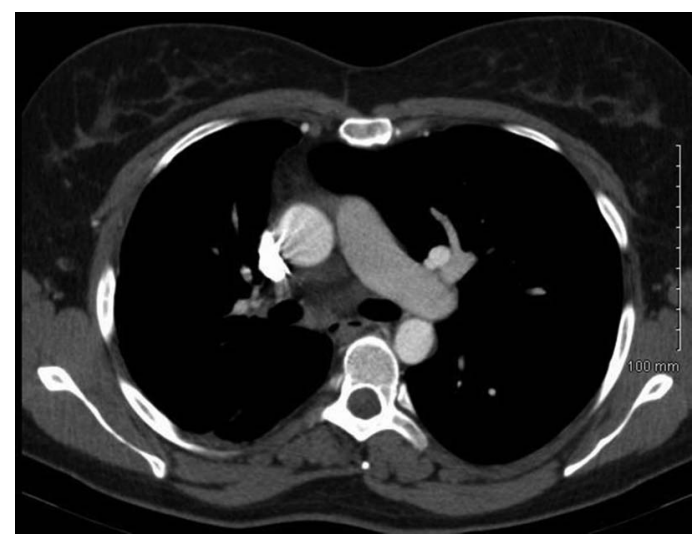

Figure 2 CT thorax showing the absence of the right pulmonary artery.

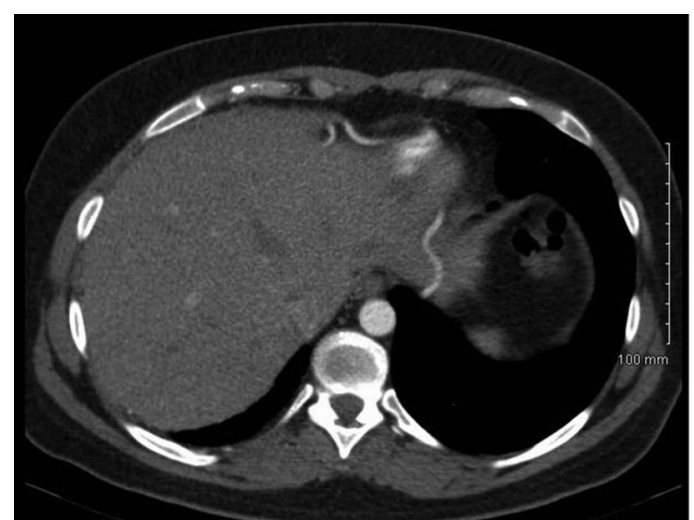

Figure 3 CT showing enlarged inferior phrenic artery.

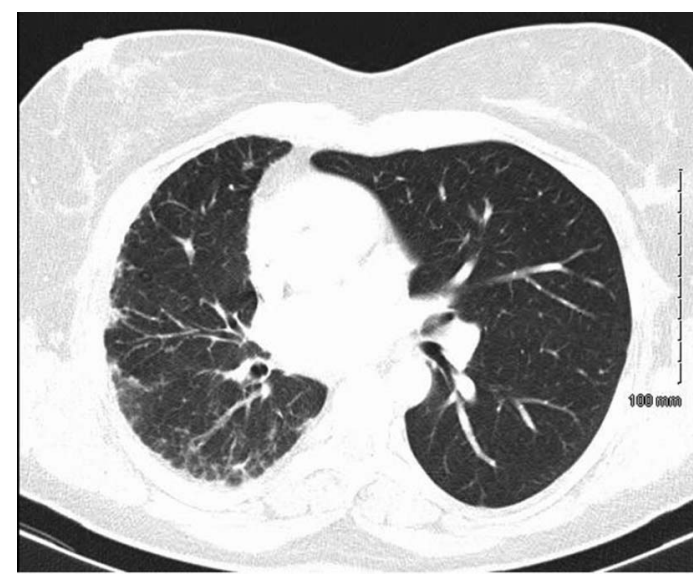

Figure 4 CT showing interstitial markings.

caused by a development anomaly of the sixth branchial arch. ${ }^{1}$

The condition may present with recurrent respiratory infections. Despite collateral circulation, the affected lung is often hypoplastic, and interstitial pulmonary pathology including bronchestasis is revealed on CT imaging. ${ }^{2}$

Complications include haemoptysis due to the rupture of collateral vessels. Management is primarily conservative. In the presence of large volume haemoptysis, systemic collateral vessels may be embolised. ${ }^{3}$

\section{Learning points}

- Agenesis of a pulmonary artery can lead to unilateral interstitial lung disease.

- CT allows evaluation of pulmonary vasculature and lung parenchyma when investigating an abnormal chest X-ray. 
Contributors DJOH is the primary author of the paper. CTOC aided critical appraisal of the submitted article and provided literature review help. TS is the consultant radiologist who reported the patient's scans and reached the correct diagnosis. $A O B$ is the consultant respiratory physician who managed the care of the patient, and provided critical appraisal of the final article.

Competing interests None declared.

Patient consent Obtained.

Provenance and peer review Not commissioned; externally peer reviewed.

\section{REFERENCES}

1 Bouros D, Pare P, Panagou P, et al. The varied manifestation of pulmonary artery agenesis in adulthood. Chest 1995;108:670-6.

2 Ten Harkel AD, Blom NA, Ottenkamp J. Isolated unilateral absence of a pulmonary artery: a case report and review of the literature. Chest 2002;122:1471-7.

3 Reñé M, Sans J, Dominguez J, et al. Unilateral pulmonary artery agenesis presenting with hemoptysis: treatment by embolization of systemic collaterals. Cardiovasc Intervent Radiol 1995;18:251-4.

Copyright 2017 BMJ Publishing Group. All rights reserved. For permission to reuse any of this content visit http://group.bmj.com/group/rights-licensing/permissions.

BMJ Case Report Fellows may re-use this article for personal use and teaching without any further permission.

Become a Fellow of BMJ Case Reports today and you can:

- Submit as many cases as you like

- Enjoy fast sympathetic peer review and rapid publication of accepted articles

- Access all the published articles

- Re-use any of the published material for personal use and teaching without further permission

For information on Institutional Fellowships contact consortiasales@bmjgroup.com

Visit casereports.bmj.com for more articles like this and to become a Fellow 